\title{
Risk Factors for the Development of Postembolization Syndrome after Transarterial Chemoembolization for Hepatocellular Carcinoma Treatment
}

\section{Fatores de Risco para o Desenvolvimento de Síndrome Pós-Quimioembolização após Quimioembolização Hepática para Tratamento de Hepatocarcinoma}

\author{
Mariana LIMA $₫ 1$, Sofia DUTRA ${ }^{2}$, Filipe Veloso GOMES ${ }^{3}$, Tiago BILHIM ${ }^{3,4}$, Élia COIMBRA ${ }^{3}$ \\ Acta Med Port 2018 Jan;31(1):22-29 - https://doi.org/10.20344/amp.8976
}

\section{ABSTRACT}

Introduction: Hepatic transarterial chemoembolization is a widely used technique for the treatment of hepatocellular carcinoma. The most common complication of this procedure is postembolization syndrome. The main objective of this study was to assess risk factors for the development of postembolization syndrome.

Material and Methods: Single-centre retrospective analysis of 563 hepatic transarterial chemoembolization procedures from January $1^{\text {st }}, 2014$ - December 31 $1^{\text {st }}, 2015$. Hepatic transarterial chemoembolization was performed with $1 / 2-2$ vials of $100-300 \mu \mathrm{m}$ microspheres loaded with doxorubicin. Patients who experienced postembolization syndrome were identified based on prolongation of hospitalization due to pain, fever, nausea and/or vomiting. A control group with the patients who did not have postembolization syndrome was randomly created (three controls for one case). Descriptive analysis and multivariate logistic regression were performed.

Results: The overall prevalence of postembolization syndrome was $6.2 \%$. Hepatic transarterial chemoembolization with doxorubicin dosage above $75 \mathrm{mg}$ (more than one vial), the size of the largest nodule and female gender had statistically significant relation with development of postembolization syndrome ( $p=0.030, p=0.046$ and $p=0.037$, respectively).

Discussion: Doxorrubicin dosage above $75 \mathrm{mg}$ is associated with a higher risk of postembolization syndrome. This result can be helpful for decision-making in clinical practice, whenever it is possible to avoid a higher dose without compromising the efficacy of the treatment. The size of the largest nodule and female gender also constitute risk factors for postembolization syndrome. The other variables studied were not related to the development of postembolization syndrome.

Conclusion: The dose of doxorrubicin, the size of the largest nodule treated and female gender are potential risk factors for the development of postembolization syndrome after hepatic transarterial chemoembolization for hepatocellular carcinoma.

Keywords: Carcinoma, Hepatocellular; Chemoembolization, Therapeutic; Radiology, Interventional; Risk Factors

\section{RESUMO}

Introdução: A quimioembolização hepática é uma técnica amplamente usada para o tratamento do carcinoma hepatocelular. A principal complicação deste procedimento é a síndrome pós-quimioembolização. O principal objetivo deste estudo foi determinar fatores de risco para síndrome pós-quimioembolização.

Material e Métodos: Análise retrospetiva unicêntrica de 563 procedimentos de quimioembolização hepática efetuados entre 1/1/201431/12/2015. A quimioembolização hepática foi efetuada com $1 / 2-2$ ampolas de microesferas 100 - $300 \mu$ m carregadas com doxorrubicina. Os pacientes que desenvolveram síndrome pós-quimioembolização foram identificados pelo prolongamento do internamento por dor, febre, náuseas e/ou vómitos. Um grupo controlo com os pacientes que não desenvolveram síndrome pós-quimioembolização foi criado de forma randomizada (três controlos para um caso). Foi realizada análise descritiva e regressão logística multivariada.

Resultados: A prevalência global de síndrome pós-quimioembolização foi 6,2\%. Quimioembolização hepática com dose de doxorrubicina superior a $75 \mathrm{mg}$ (mais de uma ampola), o tamanho do nódulo maior e o género feminino demonstraram relação estatisticamente significativa com o desenvolvimento de síndrome pós-quimioembolização ( $p=0,030, p=0,046$ e $p=0,037$, respetivamente).

Discussão: Doses de doxorrubicina superiores a $75 \mathrm{mg}$ estão associadas a maior risco de síndrome pós-quimioembolização. Este resultado pode ter impacto na prática clínica, sempre que for possível evitar doses maiores sem comprometer a eficácia do tratamento. O tamanho do maior nódulo tratado e o género feminino também constituem fatores de risco para síndrome pós-quimioembolização. As outras variáveis estudadas não demonstraram relação com síndrome pós-quimioembolização.

Conclusão: A dose de doxorrubicina, o tamanho do maior nódulo tratado e o género feminino são potenciais fatores de risco para o desenvolvimento de síndrome pós-quimioembolização após quimioembolização hepática para o tratamento de carcinoma hepatocelular.

Palavras-chave: Carcinoma Hepatocelular; Factores de Risco; Quimioembolização Terapêutica; Radiologia de Intervenção

\section{INTRODUCTION}

Hepatocellular carcinoma (HCC) constitutes the with HCC have underlying cirrhosis (80\% to 90\%) and it sixth most common cancer worldwide and the third most constitutes the leading cause of death in these patients. ${ }^{2}$ common cause of cancer death. ${ }^{1}$ The majority of patients The available treatments for HCC are: resection,

1. Serviço de Imagiologia. Hospital de Santo António dos Capuchos. Centro Hospitalar de Lisboa Central. Lisboa. Portugal.

2. Serviço de Imagiologia. Hospital do Divino Espírito Santo. Ponta Delgada. Açores. Portugal.

3. Unidade de Radiologia de Intervenção. Centro Hepato-Bilio-Pancreático e de Transplantação. Hospital Curry Cabral. Centro Hospitalar de Lisboa Central. Lisboa. Portugal.

4. Departamento de Radiologia. NOVA Medical School. Universidade Nova de Lisboa. Lisboa. Portugal.

$\bowtie$ Autor correspondente: Mariana Lima. mariana_talina@hotmail.com

Recebido: 25 de março de 2017 - Aceite: 30 de novembro de 2017 | Copyright @ Ordem dos Médicos 2018 
transplantation, ablation, transarterial chemoembolization (TACE) and sorafenib. ${ }^{3}$ The Barcelona Clinic Liver Cancer (BCLC) staging and treatment strategy defines the best therapeutic approach for HCC according to staging, which depends on tumor characteristics and performance status (including liver function). ${ }^{4}$ In the intermediate stage BCLC $B$ (multinodular liver in a patient with Child-Pugh A-B and Performance Status 0), the treatment of choice is TACE, which is palliative. ${ }^{3}$ Unfortunately, many of the patients are diagnosed at this stage and later ones. ${ }^{4}$ Furthermore, patients at an earlier stage (specially BCLC A) may benefit from TACE when there is failure of the first line therapeutic approach or recurrence. ${ }^{3}$

TACE is a procedure that consists in the local delivery of a high dose of chemotherapeutic drug to the tumor, which can be associated with particulate and/or oily embolization of its feeding arteries. ${ }^{5}$ Although it is a minimally invasive technique, it is associated with possible complications. Because it causes a hypoxic insult to the HCC and also the surrounding liver tissue, postembolization syndrome (PES) is the most common adverse event. ${ }^{6}$ It is thought to result from therapeutic cytotoxity, tumor ischemia and resulting intrahepatic and extrahepatic inflammation ${ }^{7}$ and is manifested by fever, malaise, right upper quadrant pain, nausea and vomiting. ${ }^{8}$ Its reported incidences vary widely in the literature and it has been described in as many as $60 \%$ $80 \%$ of patients. ${ }^{6,9}$ The symptoms usually develop $24-72$ hours after the procedure and PES is generally self-limited and can be treated conservatively. It usually resolves in approximately a week. ${ }^{7}$ Nevertheless, PES constitutes the main factor affecting the need and length of postprocedural hospitalization. ${ }^{5,9}$

The main objective of this study is to assess risk factors for the development of PES, either related to the patient, the characteristics of the tumor or the procedure itself.

\section{MATERIAL AND METHODS \\ Participants}

Between January $1^{\text {st }}, 2014$ and December $31^{\text {st }}, 2015$, a total of 563 TACE procedures for HCC treatment were conducted in our institution. The decision of which patients should perform TACE procedures was taken during a weekly multidisciplinary team meeting that included surgeons, hepatologists and radiologists.

The total number of patients submitted to this procedure was 276 (some patients underwent the procedure more than once during this period). All the patients subjected to TACE were included in the study. The gender distribution was 25 females and 251 males. The mean age of the patients at the time of procedure was 65 years (maximum 89, minimum 35).

The most frequent cause of cirrhosis was alcoholrelated liver disease, which accounted for $44 \%$ of the patients (121 patients). Other common cause of cirrhosis was viral infection: there were 50 patients $(18 \%)$ with hepatitis $\mathrm{C}$ virus ( $\mathrm{HCV}$ ) infection alone and 51 patients (18\%) with both HCV infection and alcohol abuse. There were also 12 patients (4\%) with cirrhosis related to hepatitis $B$ virus (HBV), 3 patients with both HBV virus infection and alcohol abuse, 4 patients with HBV plus HCV infection and one patient with all these three factors combined (HBV + $\mathrm{HCV}+$ alcohol abuse). Hemochromatosis was the cause of cirrhosis in 3 patients, and there were also 3 patients with hemochromatosis plus alcohol abuse and one patient with hemochromatosis and HCV infection. Non-alcoholic fatty liver disease (NASH) was the cause of cirrhosis in 5 patients and there were also 4 cases of cryptogenic cirrhosis and one case of auto-immune cirrhosis. Three patients with noncirrhotic livers on biopsy developed HCC. There were 14 clinical charts in which the cause of cirrhosis was not clear.

The median model for end-stage liver disease (MELD) score was 9 (range 6 - 20). Regarding the Child-Pugh classification, $85.1 \%$ of the patients were classified as Child's class A and $14.9 \%$ were classified as Child's class B.

All the patients were admitted to the hospital the day before the procedure. In this day, they performed laboratory blood tests that included complete blood count, prothrombin time (PT), international normalized ratio (INR) and biochemical tests, including total bilirubin and creatinine.

The patients submitted to TACE procedures maintained a follow-up medical appointment in our centre with a hepatobiliary surgeon. All of the patients had an appointment one and three months after the procedure.

\section{Drug-eluting microspheres transarterial chemoemboli- zation (DEM-TACE) procedure}

The TACE procedure was done transfemorally. The femoral artery was punctured according to the Seldinger method. After progression of a 5-Fr Simmons catheter (Cordis, Cardinal Health, San Francisco, CA, USA) into the relevant hepatic artery, the feeding artery was selectively catheterized with a 2.7F microcatheter (Progreat, Terumo, Tokyo, Japan). Between $1 / 2$ and 2 vials of $100-300 \mu \mathrm{m}$ microspheres loaded with doxorubicin (DC Beads, Biocompatibles, Farnham, Surrey, UK) were selectively administered. The dose administered depended on the size and vascularity of the territory treated. In some cases, additional embolics were used: lipiodol and/or polyvinyl alcohol (PVA) particles 150 - 350 micron (Contour, Boston Scientific, Natick, MA, USA). All patients were submitted to prophylactic antibiotic therapy with cephazolin $2 \mathrm{~g}$ i.v. immediately before the procedure.

\section{Data collection}

We retrospectively analysed the clinical charts of all the patients submitted to TACE to find possible complications. The analysis of the clinical charts included the hospitalization length, the inpatient and outpatient records, emergency department visits and need for re-hospitalization in the postprocedural period.

In this study, PES was defined as prolongation of hospital stay above the usual hospitalization length for this type of procedure in our institution (two days), or need for emergency department visit and/or re-hospitalization in 
the post-procedural period (first month), associated with abdominal pain, fever, nausea and/or vomiting.

Procedures followed by PES comprised the cases group. Three patients who developed PES were excluded from the cases group because of incomplete data. There were 32 procedures included in the cases group. A control group with the patients who did not have PES was randomly created, with a proportion of three controls for one case (96 procedures).

Registered variables for each TACE procedure were: age and gender of the patient; previous TACE procedures; number of nodules treated; size of the largest nodule; dose of doxorubicin administered (number of vials); administration of additional embolics (lipiodol and/or PVA particles); blood laboratory tests including total bilirubin, creatinine, albumin; INR; Child-Pugh and MELD scores; presence of ascites; embolization of the cystic artery; and segmental portal vein thrombosis.

\section{Data analysis}

Statistical analysis of the data was performed using IBM SPSS Statistics 23.0. Association between different categorical variables and the development of PES was evaluated using chi-square (Pearson) test. For variables with cells with expected count less than 5 , Fisher's exact test was used instead. Continuous variables were studied with $t$-test for independent samples and Mann-Whitney test. The Mann-Whitney test was performed to study the continuous variables that did not show a normal distribution, neither in the Shapiro-Wilk test, nor in the normal Q-Q plot. Multivariate logistic regression was also performed. A $p$-value less than 0.05 was considered statistically significant.

\section{RESULTS}

There were 45 complications registered in 41 procedures among the total of 563 TACE procedures analysed. These complications are described in Table 1. PES was the most common complication and occurred in 35 procedures, which

Table 1 - Trans-arterial chemoembolization complications. This table indicates the number of complications observed after TACE procedure, the corresponding percentage for the total number of complications and also the percentage for the total number of procedures. Some patients had more that one of the complications listed.

\begin{tabular}{lccc}
\hline Complication & $\mathbf{n}$ & $\begin{array}{c}\text { \% per complicated } \\
\text { procedures }\end{array}$ & $\begin{array}{c}\text { \% overall TACE* } \\
\text { procedures }\end{array}$ \\
\hline PES† & 35 & $85.4 \%$ & $6.20 \%$ \\
Hepatitis & 2 & $4.9 \%$ & $0.36 \%$ \\
Worsening renal function & 2 & $4.9 \%$ & $0.36 \%$ \\
Acute limb ischaemia & 1 & $2.4 \%$ & $0.18 \%$ \\
Acute pulmonary edema & 1 & $2.4 \%$ & $0.18 \%$ \\
Ascites & 1 & $2.4 \%$ & $0.18 \%$ \\
Encephalopathy & 1 & $2.4 \%$ & $0.18 \%$ \\
Hepatic abscess with sepsis & 1 & $2.4 \%$ & $0.18 \%$ \\
Puncture site hematoma & 1 & $2.4 \%$ & $0.18 \%$ \\
\hline
\end{tabular}

* Transarterial chemoembolization (TACE); † Postembolization syndrome (PES)
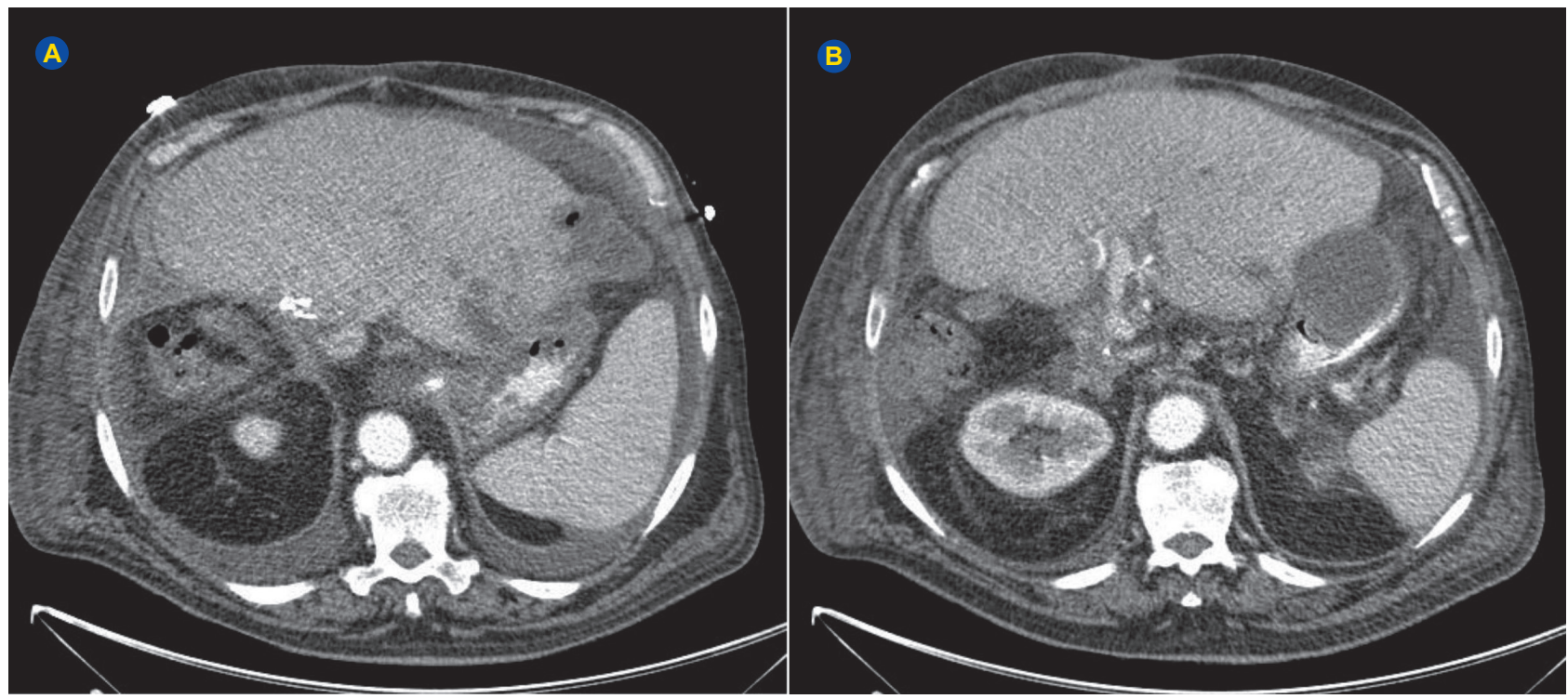

Figure 1 - On the left computed tomography axial reconstruction $(A)$, we can see a hepatic abscess that developed after trans-arterial chemoembolization. The right image of the same computed tomography (B) shows a perihepatic abscess, which deviates the lesser curvature of the stomach. 
corresponds to $6.2 \%$ of the procedures and accounted for $85.4 \%$ of all the complicated procedures after TACE. Four patients experienced more than one complication in the same TACE procedure: one patient had PES and worsening renal function, two patients had PES and hepatitis (asymptomatic elevation of aminotransferases) and another patient had ascites and worsening renal function. Other complications were isolated occurrences that included acute limb ischaemia, acute pulmonary edema, ascites, encephalopathy and puncture site hematoma.

There was one death related to the procedure. This patient returned to the hospital four days after the procedure with fever and CT scan showed the presence of a hepatic abscess and also a perihepatic abscess that deviated the lesser curvature of the stomach (Fig. 1). This patient had a previous biliodigestive anastomosis (Fig. 2). He developed sepsis and he was admitted in the intensive

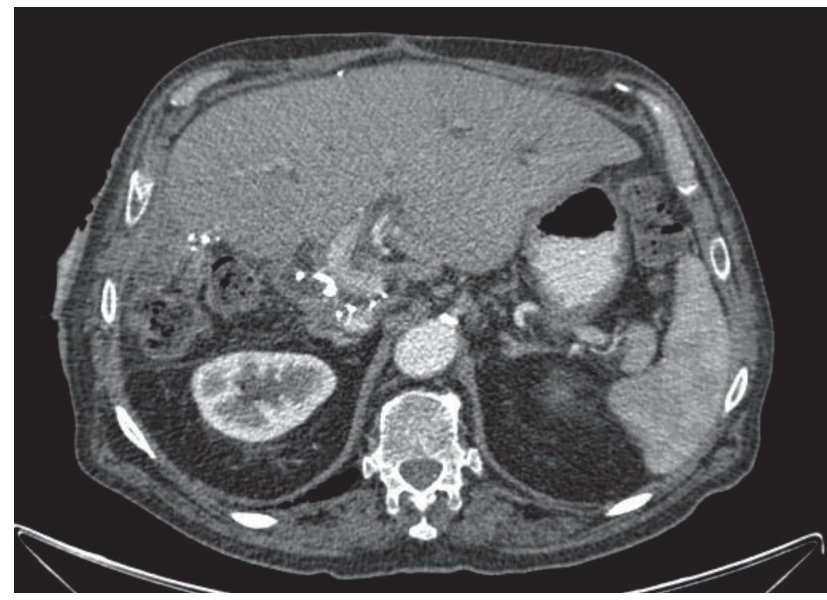

Figure 2 - Computed tomography scan showing the presence of metallic suture staples of hepaticojejunostomy

Table 2 - Categorical variables: Chi-square (Pearson)/Fisher test. This table shows the number of procedures in each category for both cases and controls, the respective percentage and the $p$-value of Pearson/Fisher tests. A p-value less than 0.05 was considered statistically significant.

\begin{tabular}{|c|c|c|c|}
\hline Variables & $\begin{array}{c}\text { Cases (PES)* } \\
\text { Total: } 32\end{array}$ & $\begin{array}{l}\text { Controls } \\
\text { Total: } 96\end{array}$ & $p$ \\
\hline $\begin{array}{l}\text { Gender }(\mathrm{n} ; \%) \\
\text { Female } \\
\text { Male }\end{array}$ & $\begin{array}{c}5 ; 15.6 \\
27 ; 84.4\end{array}$ & $\begin{array}{c}7 ; 7.3 \\
89 ; 92.7\end{array}$ & 0.173 \\
\hline $\begin{array}{l}\text { Previous TACE† procedures }(\mathrm{n} ; \%) \\
\text { Yes } \\
\text { No }\end{array}$ & $\begin{array}{l}14 ; 43.8 \\
18 ; 56.2\end{array}$ & $\begin{array}{l}54 ; 56.2 \\
42 ; 43.8\end{array}$ & 0.220 \\
\hline $\begin{array}{l}\text { Number of nodules treated }(n ; \%) \\
<5 \\
\geq 5\end{array}$ & $\begin{array}{c}29 ; 90.6 \\
3 ; 9.4\end{array}$ & $\begin{array}{c}90 ; 95.7 \\
4 ; 4.3\end{array}$ & 0.369 \\
\hline $\begin{array}{l}\text { Size of the largest nodule }(\mathrm{n} ; \%) \\
\leq 50 \mathrm{~mm} \\
>50 \mathrm{~mm}\end{array}$ & $\begin{array}{c}26 ; 81.2 \\
6 ; 18.8\end{array}$ & $\begin{array}{l}75 ; 79.8 \\
19 ; 20.2\end{array}$ & 0.858 \\
\hline $\begin{array}{l}\text { Doxorubicin dose - number of vials }(n ; \%) \\
\leq 1 \text { vial } \\
>1 \text { vial }\end{array}$ & $\begin{array}{l}13 ; 40.6 \\
19 ; 59.4\end{array}$ & $\begin{array}{l}60 ; 62.5 \\
36 ; 37.5\end{array}$ & 0.030 \\
\hline $\begin{array}{l}\text { Lipiodol }(\mathrm{n} ; \%) \\
\text { Yes } \\
\text { No }\end{array}$ & $\begin{array}{c}4 ; 12.5 \\
28 ; 87.5\end{array}$ & $\begin{array}{l}17 ; 17.7 \\
79 ; 82.3\end{array}$ & 0.491 \\
\hline $\begin{array}{l}\text { PVAł particles }(n ; \%) \\
\text { Yes } \\
\text { No }\end{array}$ & $\begin{array}{c}3 ; 9.4 \\
29 ; 90.6\end{array}$ & $\begin{array}{l}10 ; 10.4 \\
86 ; 89.6\end{array}$ & 1.000 \\
\hline $\begin{array}{l}\text { Ascites }(n ; \%) \\
\text { Yes } \\
\text { No }\end{array}$ & $\begin{array}{c}4 ; 12.5 \\
28 ; 87.5\end{array}$ & $\begin{array}{l}12 ; 12.5 \\
84 ; 87.5\end{array}$ & 1.000 \\
\hline $\begin{array}{l}\text { Segmental portal vein thrombosis }(\mathrm{n} ; \%) \\
\text { Yes } \\
\text { No }\end{array}$ & $\begin{array}{c}4 ; 12.5 \\
28 ; 87.5\end{array}$ & $\begin{array}{c}7 ; 7.3 \\
89 ; 92.7\end{array}$ & 0.465 \\
\hline $\begin{array}{l}\text { Child-Pugh score }(\mathrm{n} ; \%) \\
\text { A } \\
\text { B }\end{array}$ & $\begin{array}{c}27 ; 84.4 \\
5 ; 15.6\end{array}$ & $\begin{array}{l}82 ; 85.4 \\
14 ; 14.6\end{array}$ & 1.000 \\
\hline $\begin{array}{l}\operatorname{MELD} \S \text { score }(\mathrm{n} ; \%) \\
\leq 10 \\
>10\end{array}$ & $\begin{array}{l}22 ; 68.8 \\
10 ; 31.2\end{array}$ & $\begin{array}{l}73 ; 76.0 \\
23 ; 24.0\end{array}$ & 0.414 \\
\hline $\begin{array}{l}\text { Embolization of the cystic artery }(\mathrm{n} ; \%) \\
\text { Yes } \\
\text { No }\end{array}$ & $\begin{array}{c}2 ; 6.2 \\
30 ; 93.8\end{array}$ & $\begin{array}{c}1 ; 1.0 \\
95 ; 99.0\end{array}$ & 0.154 \\
\hline
\end{tabular}


care unit. The therapeutic measures that were provided were percutaneous ultrasound-guided drainage of the largest collection (perihepatic) and antibiotic therapy with piperacillin/tazobactam followed by meropenem. Despite that, the patient died approximately a week after the rehospitalization.

The clinical outcome of all other patients was favourable, only with conservative treatments.

Table 2 shows the results of the analysis of categorical variables with chi-square/Fisher tests. The majority of procedures consisted of the treatment of less than five nodules, both in the cases (90.6\%) and control (95.7\%) groups. There was a statistically significant difference between the two groups for the doxorubicin dose: the proportion of procedures in which it was administered more than one vial (dosage above $75 \mathrm{mg}$ ) was significantly higher in the PES group, with a $p$ value of 0.030 . For all the other categorical variables (namely the use of additional embolic agents, Child-Pugh and MELD scores, ascites, segmental portal vein thrombosis and embolization of the cystic artery) there were no statistically significant differences between the two groups using chi-square (Pearson) test/Fisher's exact test. There were only three procedures that resulted in embolization of the cystic artery (two in the cases group and one in the control group). Although the proportion of patients who had a previous TACE procedure was lower in the case group (43.8\%) when compared with the control group $(56.2 \%)$, there were no statistically significant differences between them, both with parametric and nonparametric tests.

In Table 3 we can see the results of the $t$-test for independent samples for the analysis of continuous variables. The mean age of the patients was 64 years in the PES group and 66 years in the control group. There were no statistically significant differences between the two groups using $t$-test for all continuous variables, including the size of the largest nodule. However, the mean size was higher in the PES group $(41.50 \mathrm{~mm})$ when compared to the

Table 3 - Continuous variables: $t$-test for independent samples. In this table we can see the mean \pm standard deviation for the continuous variables in the cases and control groups and the $p$-value of $t$-test for independent samples. A $p$-value less than 0.05 was considered statistically significant.

\begin{tabular}{lccc}
\hline Variables & $\begin{array}{c}\text { Cases } \\
\text { (PES) }\end{array}$ & Controls & $p$ \\
\hline Age & $64.09 \pm 10.18$ & $66.08 \pm 9.69$ & 0.323 \\
Size of the largest nodule $(\mathrm{mm})$ & $41.50 \pm 18.70$ & $35.85 \pm 20.64$ & 0.174 \\
Total bilirrubin $(\mathrm{mg} / \mathrm{dL})$ & $0.92 \pm 0.55$ & $1.00 \pm 0.49$ & 0.480 \\
Albumine $(\mathrm{g} / \mathrm{dL})$ & $3.71 \pm 0.45$ & $3.73 \pm 0.56$ & 0.850 \\
INR† & $1.14 \pm 0.15$ & $1.14 \pm 0.14$ & 0.819 \\
Creatinine $(\mathrm{mg} / \mathrm{dL})$ & $1.00 \pm 0.68$ & $0.95 \pm 0.37$ & 0.581 \\
\hline
\end{tabular}

Values in mean \pm standard deviation; * Postembolization syndrome (PES); † International normalized ratio (INR)

Table 4 - Multivariate logistic regression. This table shows the results for multivariate logistic regression, namely the odds ratio, the confidence interval and $p$-values. A $p$-value less than 0.05 was considered statistically significant.

\begin{tabular}{|c|c|c|c|}
\hline Variables & OR\| & $\begin{array}{c}\text { Confidence interval } \\
(95 \%)\end{array}$ & $p$ \\
\hline Gender & 6.848 & $1.119-41.910$ & 0.037 \\
\hline Previous TACE* procedures & 0.340 & $0.069-1.669$ & 0.184 \\
\hline Number of nodules treated & 0.998 & $0.617-1.615$ & 0.994 \\
\hline Size of the largest nodule $(\mathrm{mm})$ & 1.013 & $0.986-1.040$ & 0.364 \\
\hline Doxorubicin dose (number of vials) & 2.426 & $0.728-8.087$ & 0.149 \\
\hline Lipiodol & 0.269 & $0.049-1.491$ & 0.133 \\
\hline PVA† particles & 0.610 & $0.292-5.011$ & 0.572 \\
\hline Total bilirrubin (mg/dL) & 1.211 & $0.293-5.011$ & 0.791 \\
\hline Albumine $(\mathrm{g} / \mathrm{dL})$ & 1.389 & $0.356-5.416$ & 0.636 \\
\hline INR $\ddagger$ & 0.436 & $0.003-63.286$ & 0.744 \\
\hline Creatinine $(\mathrm{mg} / \mathrm{dL})$ & 2.391 & $0.268-21.318$ & 0.435 \\
\hline Ascites & 0.434 & $0.053-3.569$ & 0.437 \\
\hline Segmental portal vein thrombosis & 3.166 & $0.659-15.217$ & 0.150 \\
\hline Child-Pugh score & 1.229 & $0.468-3.224$ & 0.676 \\
\hline MELD§ score & 0.855 & $0.598-1.224$ & 0.394 \\
\hline Embolization of the cystic artery & 5.833 & $0.278-122.505$ & 0.256 \\
\hline
\end{tabular}

* Trans-arterial chemoembolization (TACE); † Polyvinyl alcohol (PVA); † International normalized ratio (INR); § Model for end-stage liver disease (MELD); || Odds ratio (OR) 
control group (35.85 mm). Since this variable did not show a normal distribution, we used the Mann-Whitney test. In this analysis, we found a statistically significant higher size of the largest nodule in the PES group ( $p=0.046)$.

Table 4 shows the results of the multivariate logistic regression. In this analysis we found a statistically significant difference between the two groups for gender, with a higher proportion of females in the PES group ( $p=0.037)$. There were no statistically significant differences for the other variables studied.

\section{DISCUSSION}

TACE constitutes a generally well-tolerated procedure. The incidence of major complications is described in the literature as $2 \%$ to $7 \%$, 5 and the risk of death is approximately $1 \%{ }^{8}$ We had one death among all the procedures (563), which corresponds to a mortality rate of $0.18 \%$. It occurred in a patient who developed hepatic and perihepatic abscesses and sepsis after the procedure. Infectious complications are rare after TACE because of antiseptic measures ${ }^{6}$ and the incidence of liver abscess is described in literature as $0.26 \% .{ }^{10}$ However, the incidence of post TACE liver abscess is higher among patients with bilio-enteric anastomoses, ${ }^{11}$ which was the case of this patient.

The overall incidence of PES varies in the literature and is described to occur in up to $60 \%-80 \%{ }^{6,9}$ In this study we found an incidence of PES of only $6.2 \%$. Some studies show that the complication rates (including the incidence of PES) are similar when comparing doxorubicin drug-eluting beads TACE (DEM-TACE) with conventional TACE. ${ }^{12,13}$ A study from Odisio et al, ${ }^{14}$ where they used 70 - $150 \mu \mathrm{m}$ drug-eluting beads, pointed out an incidence of PES of $67.4 \%$, which is also in the described range of $60 \%-80 \%$. However, a study from Padia et a/ ${ }^{15}$ that compared the safety of small $(100-300 \mu \mathrm{m})$ and mediumsize $(300-500 \mu \mathrm{m})$ particles, showed that the incidence of postembolization syndrome was lower in the first group and corresponded to $8 \%$. In our study, we also used $100-300$ $\mu \mathrm{m}$ beads and this rate compares better with our results. On the other hand, there are no specific findings or laboratory values to identify PES. ${ }^{7}$ The diagnosis is made clinically, based on the presence of some symptoms and signs in the post procedural period (abdominal pain, fever, nausea and/ or vomiting) and absence of other significant findings. In our study, we included in the PES group only the procedures that were associated with a prolongation of the hospitalization time or need for emergency department visiting and/or rehospitalization in the postprocedural period. This is probably the main reason why our PES incidence is much lower than the overall described $60 \%-80 \%$. However, we think that with these criteria we are including only the cases of PES that have significant clinical and economic impact.

In our study, we found that a doxorubicin dosage above $75 \mathrm{mg}$ (more than one vial) is a risk factor for the development of PES. The maximum dose used was 150 mg (two vials). Several previous studies also showed that a higher dose of chemoembolization agents (which also included doxorubicin) is associated with a higher risk of PES. 5,16,17 Taking into account that the pathogenesis of PES is multifactorial and related to the toxicity of the chemotherapeutic drug itself, which also induces an inflammatory response, ${ }^{7}$ it is expected that a higher dose of chemotherapeutic drug will be associated with an increased risk of PES. The cut-off of one vial that we found may be helpful for decision making in clinical practice, whenever it is possible to avoid a higher dose without compromising the efficacy of the treatment.

We also concluded that the size of the largest nodule treated is a risk factor for PES, although we could not find a cut-off. At least two previous studies also pointed out this risk factor and established a cut-off of $5 \mathrm{~cm}$, above which the risk of PES increases. ${ }^{2,6}$ Another study by Li et al. demonstrated that a tumor size $>3 \mathrm{~cm}$ was associated with a higher risk of PES. ${ }^{16}$ On one hand, a larger tumor size is generally associated with a higher dose used, which we already found is a risk factor for PES development. On the other hand, we saw that tumor necrosis and associated inflammatory response are also thought to be involved in PES pathogenesis, ${ }^{7}$ and a larger tumor is expected to be associated with a higher volume of necrotized tissue, if the treatment is successful.

Our results showed that female gender is related with a higher risk of PES and this association was confirmed in multivariate logistic regression. This finding was also pointed out in a previous study by Siriwardana et al. ${ }^{2}$ Another study by Wang et $a^{18}$ also showed that female gender correlates with a higher incidence of postprocedural nausea, particularly in premenopausal women. ${ }^{18}$ In that study, they found no statistically significant difference in the incidences of nausea and vomiting between male over 50 years and female patients who have entered menopause, a finding that raised the suspicion that these associations could be due to hormonal causes, namely the estradiol level. However, in our study, all women included both in the cases and control groups were postmenopausal, so this explanation is not applicable. Another aspect that would be interesting to investigate is the potential influence of body mass index (BMI), which is general lower in female patients. It was not possible to investigate this association in the present study since it is a retrospective study and the necessary data (height and weight) was not present in the clinical charts. We could also consider the possibility of this association being related with other confounding factors that can differ by gender, like the cause of cirrhosis.

In our study, the proportion of patients who had a previous TACE procedure was lower in the group that developed PES, but with no statistical significance. A previous study by Leung et $a /^{5}$ achieved similar results. Another study showed no relation between the number of previous TACE procedures and PES. ${ }^{6}$

The embolization of the cystic artery was also pointed out as a possible risk factor for the development of PES. ${ }^{5}$ In our study, this relation was not observed, although there 
were only three procedures associated with embolization of the cystic artery (two in the PES group and one in the control group).

The use of additional embolics (lipiodol and/or PVA particles) was not associated with the risk of PES. Some studies showed that lipiodol dose was associated with the risk of PES $2,6,19$ and a study by Jun et $a^{6}{ }^{6}$ established a dose $\geq 7 \mathrm{ml}$ as a cut-off. In our study, both in the PES and control group, the procedures in which injection of lipiodol occurred, the dose was always small $(\leq 6 \mathrm{ml})$ and so it was not expected to increase the risk of PES.

Child-Pugh and MELD scores were not associated with the risk of PES. A previous study also did not find relation between Child-Pugh score and the development of PES. ${ }^{6}$

The presence of ascites was pointed out in a previous study as a potential risk factor for PES. ${ }^{2}$ In our study we did not find this relation, but it is important to refer that all our cases of ascites were of small/medium volume.

The presence of segmental portal vein thrombosis and the age of the patient were not associated with PES. These factors were also not related to PES in previous studies. ${ }^{2,6}$

The main limitation of our study is its retrospective design. We had to rely on the information of the clinical charts of the patients. For the definition of PES, we applied uniform criteria to every patient to reduce our dependence on the medical registrations (time of hospitalization and emergency department visits/re-hospitalization). But if, for example, a patient had resorted to another institution with symptoms of PES in the post-procedural period, we would not have access to that information if the surgeon did not register it in the clinical chart in the usual followup appointment (one/three months after the procedure). Furthermore, regarding the laboratory data, we could only analyse the results from the blood tests performed prior to the procedure (that all patients do routinely). It was not possible to perform laboratory tests in the post-procedural period and relate them to the development of PES. Another limitation of the study is the relative small sample, although our initial group of participants was large, which is directly

\section{REFERENCES}

1. Forner A, Llovet JM, Bruix J. Hepatocellular carcinoma. Lancet 2012;379:1245-55

2. Siriwardana RC, Niriella MA, Dassanayake AS, Liyanage $C A H$, Upasena A, Sirigampala C, et al. Factors affecting post-embolization fever and liver failure after trans-arterial chemo-embolization in a cohort without background infective hepatitis - a prospective analysis. BMC Gastroenterol. 2015;15:96

3. Reig M, Darnell A, Forner A, Rimola J, Ayuso C, Bruix J. Systemic therapy for hepatocellular carcinoma: the issue of treatment stage migration and registration of progression using the BCLC-Refined RECIST. Semin Liver Dis. 2014;34:444-55.

4. Sieghart W, Hucke F, Peck-Radosavljevic M. Transarterial chemoembolization: modalities, indication, and patient selection. J Hepatol. 2015;62:1187-95.

5. Leung DA, Goin JE, Sickles C, Raskay BJ, Soulen MC. Determinants of postembolization syndrome after hepatic chemoembolization. J Vasc Interven Radiol. 2001;12:321-6.

6. Jun $\mathrm{CH}, \mathrm{Ki} \mathrm{HS}$, Lee HK, Park KJ, Park SY, Cho SB, et al. Clinical significance and risk factors of postembolization syndrome fever in patients with hepatocellular carcinoma. World J Gastroenterol. related to the small number of procedures associated with PES.

\section{CONCLUSION}

In this study, we found that female gender is related to a higher incidence of PES. This association was the only one that was further confirmed in multivariate logistic regression. The reason for this association is not yet understood and deserves future investigation.

We also found that the administration of a dose of doxorubicin above $75 \mathrm{mg}$ is associated with a higher risk of developing PES. This finding may be helpful for decision making in clinical practice, whenever it is possible to avoid a higher dose without compromising the efficacy of the treatment. The size of the largest nodule treated was also associated with the risk of development of PES after TACE for HCC treatment.

Age, Child-Pugh and MELD scores, number of nodules, embolization of the cystic artery, use of additional embolics, previous TACE procedures and segmental portal vein thrombosis were not related to the development of PES.

\section{PROTECTION OF HUMANS AND ANIMALS}

The authors declare that the procedures were followed according to the regulations established by the Clinical Research and Ethics Committee and to the Helsinki Declaration of the World Medical Association.

\section{DATA CONFIDENTIALITY}

The authors declare having followed the protocols in use at their working center regarding patients' data publication.

\section{CONFLICTS OF INTEREST}

All authors report no conflict of interest.

\section{FUNDING SOURCES}

This research received no specific grant from any funding agency in the public, commercial, or not-for-profit sectors.

7. Dhand S, Gupta R. Hepatic transcatheter arterial chemoembolization complicated by postembolization syndrome. Semin Intervent Radiol. 2011;28:207-11.

8. Clark TW. Complications of hepatic chemoembolization. Semin Intervent Radiol. 2006;23:119-25.

9. Kogut M, Chewning RH, Harris WP, Hippe DS, Padia SA. Postembolization syndrome after hepatic transarterial chemoembolization: effect of prophylatic steroids on postprocedure medication rRequirements. J Vasc Interv Radiol. 2013;24:326-31.

10. Ong GY, Changchien CS, Lee CM, Wang JH, Tung HD, Chuah SK, et al. Liver abscess complicating transcatheter arterial embolization: a rare but serious complication. A retrospective study after 3878 procedures. Eur J Gastroenterol Hepatol. 2004;16:737-42.

11. Woo S, Chung JW, Hur S, Joo S, Kim H, Jae HJ, et al. Liver abscess after transarterial chemoembolization in patients with bilioenteric anastomosis: frequency and risk factors. Am J Roentgenol. 2013;200:1370-7

12. Kucukay F, Badem S, Karan A, Ozdemir M, Okten RS, Ozbulbul NI, et al. A single-center retrospective comparison of doxorubicin-loaded 
hepaSphere transarterial chemoembolization with conventional transarterial chemoembolization for patients with unresectable hepatocellular carcinoma. J Vasc Interv Radiol. 2015;26:1622-9.

13. Huang K, Zhou Q, Wang R, Cheng D, Ma Y. Doxorubicin-eluting beads versus conventional transarterial chemoembolization for the treatment of hepatocellular carcinoma. J Gastroenterol Hepatol. 2014;29:920-5.

14. Odisio BC, Ashton A, Yan Y, Wei W, Kaseb A, Wallace MJ, et al. Transarterial hepatic chemoembolization with 70-150 $\mu \mathrm{m}$ drug-eluting beads: assessment of clinical safety and liver toxicity profile. J Vasc Interv Radiol. 2015;26:965-71.

15. Padia SA, Shivaram G, Bastawrous S, Bhargava P, Vo NJ, Vaidya S et al. Safety and efficacy of drug-eluting bead chemoembolization for hepatocellular carcinoma: comparison of small-versus medium-size particles. J Vasc Interv Radiol. 2013;24:301-6.

16. Li CP, Chao Y, Chen LT, Lee RC, Lee WP, Yuan JN, et al. Fever after transcatheter arterial chemoembolization for hepatocellular carcinoma: incidence and risk factor analysis. Scand J Gastroenterol. 2008;43:992 9.

17. Pomoni M, Malagari K, Moschouris H, Spyridopoulos TN, Dourakis S, Kornezos J, et al. Post embolization syndrome in doxorubicin eluting chemoembolization with DC Bead. Hepato-Gastroenterol. 2012;59:1156.

18. Wang S, Zhu W, Vargulick S, Lin SB, Meng Z. Nausea and vomiting after transcatheter arterial chemoembolization for hepatocellular carcinoma: incidence and risk factor analysis. Asian Pac J Cancer Prev. 2013;14:5995-6000.

19. Chan AO, Yuen MF, Hui CK, Tso WK, Lai CL. A prospective study regarding the complications of transcatheter intraarterial lipiodol chemoembolization in patients with hepatocellular carcinoma. Cancer. 2002;94:1747-52. 